\title{
Distribution of metals in Labeo coubie (Ruppel, 1832) from a National Park river in Nigeria
}

\section{*ADELAKUN, KM; IBRAHIM, AO; JOSHUA’ DA; ADEDEJI, AS; SULYMAN, A; OJO, SB}

Federal College of Wildlife Management of Forestry Research Institute of Nigeria P.M.B. 268, New Bussa, Nigeria Corresponding Author email: adelakunkehinde@gmail.com

\begin{abstract}
This study assesses heavy metals distribution in body parts of Labeo coubie (African carp) from River Oli, in Kainji Lake National Park as pollution index of the ecosystem. Fish parts samples (gills, muscles and vertebra bone) were prepared and specifically analyzed for the levels of $\mathrm{Pb}, \mathrm{Cr}, \mathrm{Zn}, \mathrm{Cu}, \mathrm{Fe}$ and $\mathrm{Cd}$ using Atomic absorption spectrophotometry. The concentration of metals in the samples at different concentrations ranged from $0.001 \pm 0.000 \mu \mathrm{g} / \mathrm{g}$ for $\mathrm{Cd}$ to $224.87 \pm 4.07 \mu \mathrm{g} / \mathrm{g}$ of $\mathrm{Fe}$ in the fish gill. There is significant $(\mathrm{p}<0.05)$ differences in the $\mathrm{Pb}$, $\mathrm{Zn}, \mathrm{Cu}$ and $\mathrm{Fe}$ concentrations across the different fish parts with gills accumulated the highest levels metals while $\mathrm{Cr}$ levels significantly $(\mathrm{p}<0.05)$ differed in the fish body parts and accumulated more in the muscles $(10.75 \pm 0.15 \mu \mathrm{g} / \mathrm{g})$. The mean concentrations of metal elements in the fish parts had shown some distinguish connection in its distributions with $\mathrm{Pb}$ and $\mathrm{Cu}$; Gills > Muscles > Vertebra bones, Fe and Zinc; Gills > Vertebra bones > Muscles while $\mathrm{Cr}$ was distributed in Muscles > Gill > Vertebra bones. However, it is revealed that Labeo coubie, a euryphagus fish probably absorb these metals through ingestion of contaminated food or absorption by the gills and bioaccumulate in different fish parts. It is therefore established that River Oli is contaminated with heavy metals as presence of these metals in fish is an indication of its immediate environment.
\end{abstract}

\section{DOI: $\underline{\text { https://dx.doi.org/10.4314/jasem.v25i3.3 }}$}

Copyright: Copyright (C) 2021 Adelakun et al. This is an open access article distributed under the Creative Commons Attribution License (CCL), which permits unrestricted use, distribution, and reproduction in any medium, provided the original work is properly cited.

Dates: Received: 12 December 2020; Revised: 26 January 2021; Accepted: 12 February 2021

Keywords: absorption, bioaccumulation, fish parts, heavy metals, pollution

Environmental pollution is generally defined as the contamination of water, soil, or the atmosphere by the discharge of substances that are harmful to living things (Obianime et al., 2017). In this realm, heavy metals are typical pollutants in aquatic environments which are of immediate concern due to their persistence in the environment and toxicity to humans (Alhassan et al., 2016). In different water bodies, heavy metal pollution results from direct atmospheric deposition, geologic weathering or through the discharge of agricultural, municipal, residential or industrial waste products (Dhanakumar et al., 2015; Garcia et al., 2015 and Demirak et al., 2006) and they can have a negative impact on aquatic ecosystems, the food chain and human health (Arantes et al., 2016). Heavy metals can be taken up into fish either from ingestion of contaminated food via the alimentary tract or through the gills and skin (Sfankianakis et al., 2015 and Drevnick et al., 2006). The quantification of potential contaminants in fish tissues can be an important part of water quality assessment programs (Oliveira-Ribeiro et al., 2005) because it can reflect levels found in sediment and water and its distribution in the particular aquatic environment from which they are sourced (Nhiwatiwa et al., 2011). Heavy metals have been reported to change the genetic, physiological, biochemical and behavioral parameters of aquatic organisms including fish (Mahboob et al., 2016). Fish have been the most popular choice as test organisms for heavy metals because they are presumably the best understood organisms in the aquatic environment and are an important source of protein to man (Murtala et al., 2012). Accumulated heavy metals may lead to morphological alterations in the tissues of fish (Monteiro et al., 2005) and many cause death or sub-lethal pathology of liver, kidneys, reproductive system, respiratory system or nervous system in both invertebrate and vertebrate aquatic animals (Mahboob et al., 2016). However, heavy metals have devastating effects on ecological balance of the recipient environment and a diversity of aquatic organisms (Farombi et al., 2007). Concentrations of these heavy metals in the fish tissues are a critical issue that needs to be addressed as levels of metals in fish usually reflects its presence in water and sediment of the particular water body. There is need for a better understanding of heavy metals composition in different body parts of fish. Therefore, this study 
assesses distribution of heavy metals in Labeo coubie (African carp) parts (muscles, gills and vertebra bones) from Kainji Lake National Park. This research is essential if wildlife ecological balance of the park is to be sustained from the metals adverse effects especially with regard to water dependent species.

\section{MATERIALS AND METHOD}

Study location: Kainji Lake National Park is located in the North West-central part of Nigeria between latitude $9^{0} 45^{\prime} \mathrm{N}$ and $10^{0} 23^{\prime} \mathrm{N}$ and longitude $3^{\circ} 4^{\prime} \mathrm{E}$ and $5^{0} 47^{\prime} \mathrm{E}$. It is made up of two sectors (Borgu and Zugurma) situated in Borgu and Kaima/Baruten Local Government Areas of Niger and Kwara State, respectively. It covers a total land area of 5,340.825 $\mathrm{Km}^{2}$ (Ayeni, 2007). Kainji Lake National Park was established in 1979 by the amalgamation of two formal game reserves Borgu and Zugurma under decree 46 of $29^{\text {th }}$ July 1997 , thereby making Kainji Lake National Park the premier National Park in Nigeria (Ayeni, 2007). River Oli is the major river in the Park that supports the lives of aquatic and terrestrial wildlife species and domestic animals. The farmers and their families in the villages that share boundaries with the Park also depend on the river for their livelihood both in the dry and wet seasons.

Fish sampling and processing: Five sub-adult specimen of Labeo coubie (African carp) were caught weekly using gill nets for ten weeks from River Oli and transported to the laboratory.

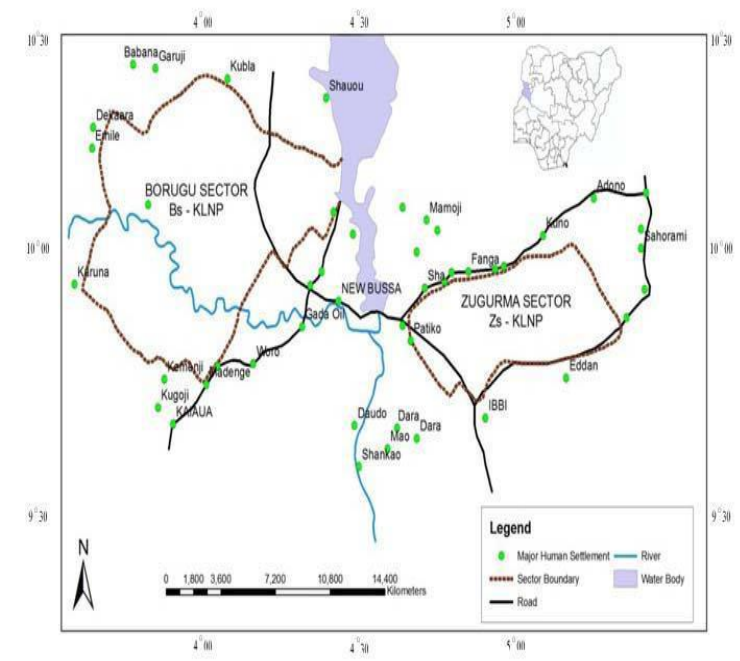

Fig 1. Kainji Lake National Park Showing River Oli and major human settlements (Ayeni, 2007)

A clean-washed high-quality corrosion-resistant stainless knife was used to cut $1 \mathrm{~g}$ wet weight of the fish tissue (muscles) along the lateral line. The operculum of each fish sample was opened and the gill removed while whole fish was dissected to remove vertebra bone. After dissection, all the samples were labeled accordingly. The entire samples (gills, muscles and vertebra bone) of each fish species were separately dried in a laboratory oven at $175^{\circ} \mathrm{C}$ for 3 hours. The dried samples were each ground with laboratory ceramic mortar and pestle to powder and sieved with $2 \mathrm{~mm}$ sieve. After being ground, the samples were heated at the temperature of $45^{\circ} \mathrm{C}$ in a muffle furnace till the aroma of the sample disappeared. The powdered samples were digested according to procedures described by Novozamsky et al. (1983). The digested samples were diluted with de-ionized distilled water appropriately and filtered using a 0.5 micron filter membrane. The digested samples were poured into auto analyser cups and concentration of Lead $(\mathrm{Pb})$, Cadmium (Cd), Iron ( $\mathrm{Fe})$, Chromium $(\mathrm{Cr})$, Zinc $(\mathrm{Zn})$ and Copper $(\mathrm{Cu})$ in each sample $(\mu \mathrm{g} / \mathrm{g})$ were determined with Atomic Absorption Spectrophotometry (AAS) Perkin-Elmer spectrophotometer (AAnalyst 200 model) using their respective lamps and wavelengths in the laboratory. Operational conditions (such as lamp selection and wavelength) were adjusted to yield optimal determination. The machine was standardized by aspirating distilled water to obtain zero absorbance. The samples were aspirated into the machine and absorbance value was read and recorded.

Data analysis: Data obtained were statistically analysed using ANOVA in SPSS 18 and $\mathrm{p}<0.05$ were considered to indicate statistical significance while the means were compared and separated using Duncan's Multiple Range Test (DMRT) as a post-hoc test (Steele and Torrie, 1980).

\section{RESULTS AND DISCUSSION}

Heavy metals concentrations in different body parts (muscles, gills and vertebra bones) of Labeo coubie: The mean concentration of heavy metals in the fish body parts were presented in table 1 . The results show that there are metals bioaccumulated in the samples at different concentrations ranged from below detectable level (BDL) of $\mathrm{Cd}$ to $224.87 \pm 4.07 \mu \mathrm{g} / \mathrm{g}$ of $\mathrm{Fe}$ in the fish gills. There is significant $(\mathrm{p}<0.05)$ differences in the $\mathrm{Pb}$ concentrations in the different fish parts with gills accumulated the highest level $(3.20 \pm 0.16 \mu \mathrm{g} / \mathrm{g})$. Chromium levels significantly $(\mathrm{p}<0.05)$ differed in the fish body parts and accumulated more in the muscles $(10.75 \pm 0.15 \mu \mathrm{g} / \mathrm{g})$ where $\mathrm{Zn}$ concentration is relatively lower $(14.75 \pm 0.04 \mu \mathrm{g} / \mathrm{g})$ compares to $29 \pm 10.87 \mu \mathrm{g} / \mathrm{g}$ and $30.60 \pm 2.49 \mu \mathrm{g} / \mathrm{g}$ found in vertebra bones and gills respectively. $\mathrm{Cu}$ accumulation in muscles $(27.35 \pm 0.23$ $\mu \mathrm{g} / \mathrm{g})$ and vertebra bone $(25.65 \pm 5.54 \mu \mathrm{g} / \mathrm{g})$ demonstrate no significant difference $(\mathrm{p}>0.05)$ but the concentration is significantly higher $(\mathrm{p}<0.05)$ in the gills with $53.55 \pm 3.23 \mu \mathrm{g} / \mathrm{g}$. Fe in all fish parts are 
relatively high and ranged from $180.33 \pm 4.19 \mu \mathrm{g} / \mathrm{g}$ in fish muscles to a significant high value of $224.87 \pm 4.07$ $\mu \mathrm{g} / \mathrm{g}$ in the gills. There are low levels of $\mathrm{Cd}$ in the fish samples where concentration in gill is below detectable level while $0.001 \pm 0.000$ and $0.001 \pm 0.001$ were recorded for muscles and vertebra bones respectively. Figure 2 depicted the mean concentrations of heavy metals in different body parts of the fish against the maximum tolerable level as recommended by World Health Orgainsation, 2008. $\mathrm{Pb}$ levels in muscles and bones are lower but its concentration of $3.20 \pm 0.16 \mu \mathrm{g} / \mathrm{g}$ in the gills is exceed $2 \mu \mathrm{g} / \mathrm{g}$ maximum tolerable level recommended. $\mathrm{Cr}$ levels that ranged from $0.35 \pm 0.04 \mu \mathrm{g} / \mathrm{g}$ and $10.75 \pm 0.15 \mu \mathrm{g} / \mathrm{g}, \mathrm{Zn}(14.75 \pm 0.04 \mu \mathrm{g} / \mathrm{g}$ and $30.60 \pm 2.49$ $\mu \mathrm{g} / \mathrm{g})$ and $\mathrm{Cd}(0.001 \mu \mathrm{g} / \mathrm{g})$ are below tolerable level of $50 \mu \mathrm{g} / \mathrm{g}(\mathrm{Cr}), 75 \mu \mathrm{g} / \mathrm{g}(\mathrm{Zn})$ and $<1(\mathrm{Cd})$ recommended for corresponding elements. More also $\mathrm{Fe}$ concentrations in all fish parts are considerably above the allowable limit of $100 \mu \mathrm{g} / \mathrm{g}$ while only $\mathrm{Cu}$ level of $53.55 \pm 3.23 \mu \mathrm{g} / \mathrm{g}$ in gills exceeded the acceptable level of $30 \mu \mathrm{g} / \mathrm{g}$. Presence of some these metals at high concentrations are considered as a dangerous source of water pollution, because of its consequential effects on the aquatic resources. These metals are known to induce oxidative stress and/or carcinogenesis by mediating free radicals/reactive oxygen species (Javed et al., 2015). At trace levels, some heavy metals (e.g. $\mathrm{Cu}, \mathrm{Fe}, \mathrm{Zn}$ and $\mathrm{Cr}$ ) are essential to maintain important biological roles including metabolism of the biological organism such as fish (Abadi et al., 2014) while inadequate supply of these micronutrients could results in a variety of deficiency diseases or syndromes (Kennedy, 2011). However, toxicity could also occur at excessive concentration of these metals (Sivaperumal et al., 2007) leading to a variety of adverse effects and fish diseases. On the other hand, non-essential metals such as $\mathrm{Cd}$ and $\mathrm{Pb}$ have no proven biological function and their toxicity rises with increasing concentrations (Sfakianakis, 2015) and therefore can lead to poisoning (Binkowski, 2012). From the study, the presence of heavy metals in the different body parts of Labeo coubie confirmed the report that heavy metals entering the water bodies can be deposited into aquatic organisms through the effects of bioconcentration, bioaccumulation and the food chain process (Abdel-Baki et al., 2011). It is further evident that heavy metals accumulate in the fish muscles, internal organs and bones as earlier reported in various studies (Kehinde and Adelakun, 2019; Agbon and Omoniyi, 2010; Golonova, 2008 and Dural et al., 2007). Presence of $\mathrm{Pb}$ in all fish parts examined in the study agreed with Omwenga, (2003) that $\mathrm{Pb}$ accumulates in the bones and soft tissues of fish. Aquatic organisms bio accumulate $\mathrm{Pb}$ from water and diet, although there is evidence that $\mathrm{Pb}$ accumulation in fish, is most probably originated from contaminated water rather than diet (Creti et al., 2010). Although $\mathrm{Pb}$ is a naturally occurring substance, its environmental concentrations are significantly increased by anthropogenic sources including lead containing pesticides, through precipitation, fallout of lead dust, road runoff, and community wastewater (Sepe, 2003). Lead $(\mathrm{Pb})$ concentrations recorded in the study (table 1) are comparatively higher to the findings of Okafo et al., (2018), who reported range of $0.30 \pm 0.15 \mu \mathrm{g} / \mathrm{g}$ and $0.39 \pm 0.18 \mu \mathrm{g} / \mathrm{g}$ for Labeo species from River Kaduna. Similarly, lower concentrations ranges between $0.002 \pm 0.001 \mu \mathrm{g} / \mathrm{g}$ to $0.024 \pm 0.004 \mu \mathrm{g} / \mathrm{g}$ in gills and $0.002 \pm 0.000 \mu \mathrm{g} / \mathrm{g}$ to $0.004 \pm 0.001 \mu \mathrm{g} / \mathrm{g}$ in muscles of economic important fishes of Aiba reservoir, Nigeria has been documented (Atobatele and Olutona, 2015). However, even at low levels, $\mathrm{Pb}$ pollution could cause some adverse effects on fish health and reproduction (Delistry and Stone, 2007).

Highest accumulation of $\mathrm{Pb}$ found in gills from the study affirmed its deposition in various fish organs including fish gills (Jezierska and Witeska, 2006), leading to disorders in fish body. The characteristic symptoms of chronic $\mathrm{Pb}$ toxicity include changes in the blood parameters with severe damage to erythrocytes and leucocytes and damage in the nervous system (El Badawi, 2005). The concentration of $\mathrm{Cr}$ significantly varied in all samples and below the tolerable level of $50 \mu \mathrm{g} / \mathrm{g}$ (WHO, 2008), though higher than the concentrations of $0.02 \pm 0.01 \mu \mathrm{g} / \mathrm{g}$ to $0.40 \pm 0.13 \mu \mathrm{g} / \mathrm{g}$ in the different organs of the six species of fishes from Lake Chad in Doron Buhari, Maiduguri, Borno State, Nigeria (Akan et al., 2009). Chromium is an essential nutrient metal, necessary for metabolism of carbohydrates (Farag et al., 2006). Fish assimilate $\mathrm{Cr}$ by ingestion or by the gill uptake tract and accumulation in fish tissues, mainly liver, occurs at higher concentrations than those found in the environment (Pacheco et al., 2013 and Ahmed et al., 2013). The overall toxic impact on organs like gill, kidney and liver may seriously affect the metabolic, physiological activities and could impair the growth and behavior of fish (Vinodhini and Narayanan, 2008). Toxic effects of $\mathrm{Cr}$ in fish include: hematological, histological and morphological alterations, inhibition/reduction of growth, production of reactive oxygen species (ROS) and impaired immune function (Reid, 2011 and Vera-Candioti et al., 2011). The mean levels of $\mathrm{Zn}$ in this study fall within $14.56 \pm 0.48 \mu \mathrm{g} / \mathrm{g}$ and $51.82 \pm 2.75 \mu \mathrm{g} / \mathrm{g}$ reported for Chrysichthys nigrodigitaus in the same study area (Adelakun and Kehinde, 2019), much higher than 2.19 $\pm 0.39 \mu \mathrm{g} / \mathrm{g}$ reported for Labeo species from River Kaduna (Okafo et al., 2018) but lower than $65.33 \mu \mathrm{g} / \mathrm{g}$ documented for Tilapia Zilli from the lower reaches of River Niger (Obodo, 2002). Zn plays a vital role in the 
physiological and metabolic process of many organisms (Rajappa et al., 2010). It is essential element in animal diet because it helps in protein synthesis (Amundsen et al., 1997) but may be become toxic to fish at concentration above $75 \mu \mathrm{g} / \mathrm{g}$ (WHO, 2008) and could result to mortality, growth retardation, and reproductive impairment (Giardina et al., 2008). However, Zinc does not appear to present a contaminant hazard to Labeo coubie within the River Oli catchment of Kainji Lake National Park. For Cu, which can get into aquatic ecosystems from diverse sources for example, from $\mathrm{Cu}$ compounds used in agro chemicals, wood preservatives, tie and dye manufacture (Akan et al., 2010). Also, from $\mathrm{Cu}$ compounds added in fertilizers and animal feeds as a nutrient to support plant and animal growth. $\mathrm{Cu}$ recorded in the study is higher than $7.04 \pm 0.03 \mu \mathrm{g} / \mathrm{g}$ in Chrysichthys nigrodigitatus and $9.51 \pm 0.10 \mu \mathrm{g} / \mathrm{g}$ in Parachanna obscura from Ibiekuma stream, Ekpoma, Nigeria (Erhabor et al., 2010) as well as $1.57 \pm 0.26$ $\mu \mathrm{g} / \mathrm{g}$ in Cynothrissa mento from Ologe Lagoon, Lagos, Nigeria (Kumolu-Johnson et al., 2010) but is lower than the range of $860-1620 \mu \mathrm{g} / \mathrm{g}$ reported by Anetekhai et al. (2007) in M. vollenhovenii (a non-fin fish) from the same Ologe Lagoon. This has been associated to greater metal load in Ologe Lagoon because of the presence of Agbara Industrial Estate, which discharges its waste into the lagoon (Kusemiju et al., 2001). However, $\mathrm{Cu}$ concentration in gills of the fish in the present study exceeded maximum tolerable level of 30 $\mu \mathrm{g} \mathrm{kg}-1$ (WHO, 2008) and high doses of $\mathrm{Cu}$ may cause anaemia, liver and kidney damage, stomach and intestinal irritation (Tirkey et al., 2012). The high $\mathrm{Cu}$ levels in Labeo coubie in the study could be attributed to agricultural activities in the catchment especially the use fertilizers and agro chemicals. The River Oli catchment is a high potential area for agricultural practices including crops farming and animal husbandry, therefore $\mathrm{Cu}$ compounds added in fertilizers and animal feeds get into river through surface runoff especially during the rainy season. This study show that Iron $(\mathrm{Fe})$ is the most bioaccumulated of all metals in the fish body parts (Table 1), though fall within $126.23 \pm 0.06 \mu \mathrm{g} / \mathrm{g}$ and $560.63 \pm 0.03 \mu \mathrm{g} / \mathrm{g}$ reported for different body parts of Chrysichthys nigrodogitatus and Parachanna obscura from Ibiekum stream, Nigeria (Erhabor et al., 2010). However, the values reported for $\mathrm{Fe}$ in the study exceed maximum tolerable level of $100 \mu \mathrm{g} / \mathrm{g}$ (WHO,

Table 1. Mean $( \pm)$ concentration of heavy metals in muscles, gill
2008). High concentration of Fe in fish gills as evident in the study could cause respiratory distress in fish due to physical clogging of the gills (Dalzell and Macfarlane, 1999) because the precipitated Fe compounds could reduce the gills area available for respiration causing damage to the respiratory epithelium and eventual suffocation of the fish (Abbas et al., 2002). This investigation revealed that $\mathrm{Cd}$ values obtained in this study fall within $0.002 \pm$ $0.000 \mu \mathrm{g} / \mathrm{g}$ reported for muscles of Labeo species in Aiba reservoir, Nigeria (Atobatele and Olutona, 2015). However, small quantities of cadmium could interfere with fish enzymes and cause diseases (Rajappa et al., 2010) including bone defects in animals (Tirkey et al., 2012). Cd was practically less bioaccumulated by the sampled fish species in this study. This could be attributed to the fact that the fishes were conceivably able to excrete the metal at a rate that exceeded the uptake of the metal (Wangboje et al., 2013).

Patterns of heavy metals accumulation in body parts (muscles, gills and vertebra bones) of Labeo coubie: The mean concentrations of metal elements in the fish parts had shown some connection in its bioaccumulation patterns. $\mathrm{Pb}$ and $\mathrm{Cu}$ had similar bioaccumulation forms of Gills > Muscles > Vertebra bones. Fe and Zinc, which are important essential metals exhibited Gills > Vertebra bones > Muscles accumulation pattern while $\mathrm{Cr}$ differed with all other metals forms with Muscles > Gill > Vertebra bones order of bioaccumulation in Labeo coubie (see table 2 ). It is apparent from the study that gill samples accumulated highest level of $\mathrm{Pb}, \mathrm{Cu}, \mathrm{Zn}$ and $\mathrm{Fe}$, thus corroborated Storelli et al. (2006) and Rashed (2001); that gill is the centre of metal accumulation in fish as a results of its important role in interface with the environment in performing its functions in gas exchange, ion regulation, acid balance and waste excretion (Bajc et al., 2005; Filazi et al., 2003; Shukla et al., 2007). The distribution pattern (gills < muscles $<$ bones) of most metals in the study conformed closely with the work done by (Golonova, 2008) this could be as a result of gills direct metal uptake from water (Storelli et al., 2006) which can be influenced by absorption of metals on to the gill surface (Erdogrul and Erbilir, 2007; Dural et al., 2006) while muscles (Uysal et al. 2009; Bervoets and Blust, 2003) and bones (Akan et al., 2009) comparably considered to have weak accumulation potential. weight).

\begin{tabular}{cllllll}
\hline Fish parts & \multicolumn{7}{l}{ The mean concentration of heavy metals in fish flesh $(\mu \mathrm{g} / \mathrm{g})$} & & \\
\hline & $\mathbf{P b}$ & $\mathbf{C r}$ & $\mathbf{Z n}$ & $\mathbf{C u}$ & $\mathbf{F e}$ & $\mathbf{C d}$ \\
Muscles & $1.50 \pm 0.02^{\mathrm{b}}$ & $10.75 \pm 0.15^{\mathrm{c}}$ & $14.75 \pm 0.04^{\mathrm{a}}$ & $27.35 \pm 0.23^{\mathrm{a}}$ & $180.33 \pm 4.19^{\mathrm{a}}$ & $0.001 \pm 0.000$ \\
Gills & $3.20 \pm 0.16^{\mathrm{c}}$ & $3.80 \pm 0.22^{\mathrm{b}}$ & $30.60 \pm 2.49^{\mathrm{b}}$ & $53.55 \pm 3.23^{\mathrm{b}}$ & $224.87 \pm 4.07^{\mathrm{b}}$ & $\mathrm{BDL}$ \\
Bones & $0.45 \pm 0.02^{\mathrm{a}}$ & $0.35 \pm 0.04^{\mathrm{a}}$ & $29 \pm 10.87^{\mathrm{b}}$ & $25.65 \pm 5.54^{\mathrm{a}}$ & $196.30 \pm 21.00^{\mathrm{a}}$ & $0.001 \pm 0.001$ \\
\hline
\end{tabular}

Note: Values are mean values \pm standard error. Mean with different superscript within the same column are significantly different $(p<0.05)$ 


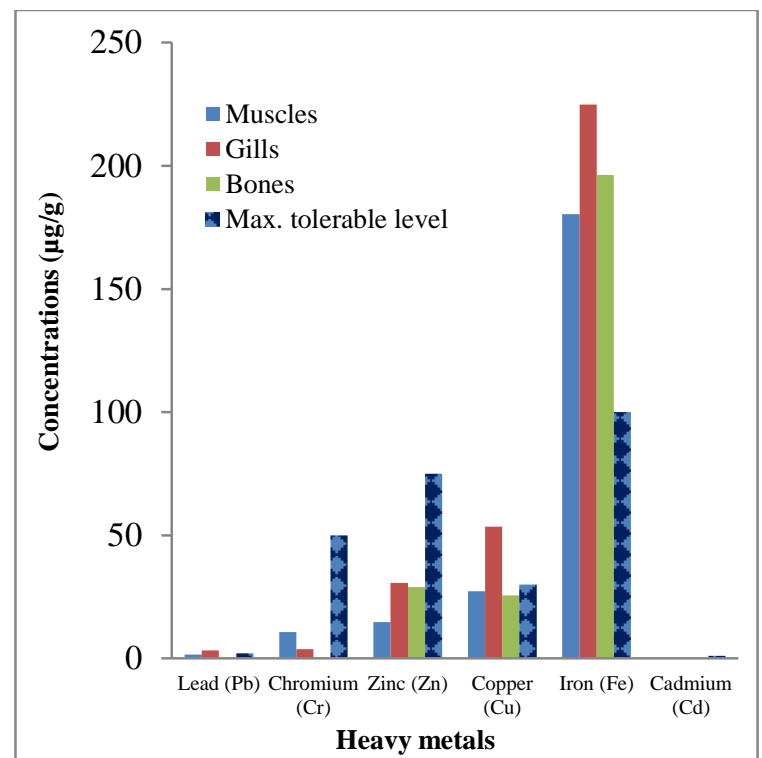

Fig 2. Mean concentrations of heavy metals in the muscles, gills and vertebra bones of Labeo coubie from the study area against WHO (2008) maximum tolerable level.

Table 2. Bioaccumulation patterns of heavy metals in body parts (muscles, gills and vertebra bones) of Labeo coubie

\begin{tabular}{ll}
\hline Metal elements & $\begin{array}{l}\text { Pattern of the bioaccumulation of } \\
\text { heavy metal fish parts }\end{array}$ \\
\hline $\mathbf{P b}$ & Gills > Muscles $>$ Vertebra bones \\
$\mathbf{C r}$ & Muscles $>$ Gill > Vertebra bones \\
$\mathbf{Z n}$ & Gills > Vertebra bones > Muscles \\
$\mathbf{C u}$ & Gills > Muscles > Vertebra bones \\
$\mathbf{F e}$ & Gills > Vertebra bones > Muscles \\
\hline
\end{tabular}

Conclusion: There is the possibility of the heavy metals originating from the chemical fertilizers and all forms of pesticides in the surrounding communities of the Park possibly being washed down into the river through runoff. Hence, Labeo coubie, a euryphagus fish probably absorb these metals through ingestion of contaminated food or by absorption by the gills and bioaccumulate in different body parts. It is then pertinent to facilitates appropriate action towards protection and sustainable environment for wildlife conservation in the Park and its surrounding communities.

\section{REFERENCES}

Abadi, DRV; Dobaradaran, S; Nabipour, I; Lamani, X; Ravanipour, M; (2014). Comparative investigation of heavy metal, trace, and macro element contents in commercially valuable fish species harvested off from the Persian Gulf. Environ Sci Pollut Res.

Abbas, HH; Zaghloul, KH; Mousa, MA (2002). Effect of some heavy metal pollutants on some biochemical and histopathological changes in
Blue tilapia, Oreochromis aureus. Egypt. J. Agric. Res., 80: 1395-1411.

Adelakun, KM; Kehinde, AS (2019). Heavy metals bioaccumulations in Chrysichthys nigrodigitatus (Silver catfish) from River Oli, Kainji Lake National Park, Nigeria. Egyptian Journal of Aquatic Biology \& Fisheries 23(5): 253 - 259

Agbon, AO; Omoniyi, IT (2010). Heavy metals in some Fish species of Oyan Lake, Southwest Nigeria. Nig. J. Fisheries. Vol.7 No1 and 2: 91 99.

Ahmed, MK; Kundu, GK; Al-Mamun, MH; Sarkar, SK; Akter, MS; Khan, MS (2013). Chromium (VI) induced acute toxicity and genotoxicity in freshwater stinging catfish, Heteropneustes fossilis. Ecotoxicol. Environ. Saf. 92: 64-70.

Akan, JC; Abdulrahman, FI; Sodipo, OA; Akandu, PI (2009). Bioaccumulation of Some Heavy Metals of Six Fresh Water Fishes Caught from Lake Chad in Doron Buhari, Maiduguri, Borno State, Nigeria. J. Appl. Sci. Environ. Sanit. 4 (2): 103114.

Akan, JC; Abdulrahman, FI; Sodipo, OA; Chiroma, YA (2010). Distribution of Heavy Metals in the Liver, Kidney and Meat of Beef, Mutton, Caprine and Chicken from Kasuwan Shanu Market in Maiduguri Metropolis, Borno State, Res. J. Appl. Sci. Eng. Tech. 2(8): 743-748.

Alhassan, AB; Balarabe, ML; Gadzama, IMK (2016). Assessment of some heavy metals in macrobenthic invertebrate and water samples collected from Kubanni reservoir, Zaria, Nigeria. Federal University Wukari Trends in Sci. Tech. J. 1(1):55-60.

Amundsen, PA; Staldvilk, FJ; Lukin, A; Kashulin, N; Popova, O; Restetnikov, Y (1997). Heavy metals contaminations in fresh water fish form the border region between Norway and Russia. Sci. Total Environ. 201:211-4.

Anderson, RA (2005). Essentiality of Chromium in Humans. Sci. Total Environ. 86; 75-81

Anetekhai, MA; Akin-Oriola, GA; Aderinola, OJ; Akintola, SL (2007). Trace metal concentration in Macrobrachium vollenhovenii from Ologe Lagoon, Lagos, Nigeria. J. Afrotrop. Zool., Special Issue: 25-29. 
Arantes, FP; Savassi, LA; Santos, HB; Gomes, MVT; Bazzoli, N (2016). Bioaccumulation of mercury, cadmium, zinc, chromium, and lead in muscle, liver and spleen tissues of a large commercially valuable catfish species from Brazil. Annals of the Brazilian Academy of Sciences, doi.org/10.1590/0001-3765201620140434

Atobatele, OE; Olutona, GO; (2015). Distribution of three non-essential trace metals (Cadmium, Mercury and Lead) in the organs of fish from Aiba Reservoir, Iwo, Nigeria. Toxicology Reports 2 (2015) 896-903.

Ayeni, JSO (2007). Participatory management plan in Kainji Lake National Park. ENVIRONCONSULT: Lagos. 156p.

Bajc, Z; Gacnik, KS; Jenci, V; Doganoc, DZ (2005). The Content of $\mathrm{Cu}, \mathrm{Zn}$ and $\mathrm{Mn}$ in Slovenian freshwater fish. Slov. Vet. Res., 42, 15-21.

Bervoets, L; Blust, R (2003). Metal concentrations in water sediment and gudgeon (Gobiogobio) from a pollution gradient: relationship with fish condition factor. Environ. Pollut. 126: 9-19.

Binkowski, MN (2012). Preliminary results of cadmium and lead concentration in pectoral muscles of mallards and coots shot in 2006 in southern Poland, J. Microbiol. Biotech. Food Sci. 1: $120-1128$.

Cretì, P; Trinchella, F; Scudiero, R (2010). Heavy metal bioaccumulation and metallothionein content in tissues of the sea bream Sparus aurata from three different fish farming systems. Environ. Monit. Assess. 165: 321-329.

Dalzell, DJB; Macfarlane, NAA (1999). The toxicity of iron to brown trout and effects on the gills: a comparison of two grades of iron sulphate. J. Fish Biol. 55: 301-315.

Delistraty, D; Stone, A (2007). Dioxins, metals, and fish toxicity in ash residue from space heaters burning used motor oil. Chemosphere 68(5): $907-$ 914.

Demirak, A; Yilmaz, F; Levent-Tuna, A; Ozdemir, N (2006). Heavy metals in water, sediment and tissues of Leuciscus cephlaus from a stream in southwestern Turkey. Chemosphere 63: 14511458.
Dhanakumar, S; Solaraj, G; Mohanraj; R (2015). Heavy metal partitioning in sediments and bioaccumulation in commercial fish species of three major reservoirs of river Cauvery delta region, India. Ecotoxicol. Environ. Saf. 113: 145151.

Drevnick, PE; Sandheinrich, MB; Oris, JT (2006). Increased ovarian follicular apoptosis in fathead minnows (Pimephales promelas) exposed to dietary methylmercury. Aquat Toxicol 79: 49-54.

Dural, DA; Bakare, OK; Ayodele, IA (2007). Trade in the wild mammalian Species for Traditional medicine in Ogun State, Nig. Global J. Med. Res. 12 (3): 6-21.

Dural, M; Goksu, MZI; Ozak, AA; Derici, B (2006) Bioaccumulation of some heavy metals in different tissues of Cicentrarchus labrax L., 1758, Sparus aurata L.,1758 and Mugli cephalus L., 1758 from the Camlik Lagoon of the Eastern Coast of Mediterranean (Turkey). Environ. Monit. Assess. 118: 66-74.

El-Badawi, AA (2005). Effect of lead toxicity on some physiological aspects of Nile tilapia fish, Oreochromis niloticus. In: Inter. Conf. Vet. Res. Div., 2005, NRC, Cairo, Egypt.

Erdogrul, O; Erbilir, F (2007). Heavy metals and trace elements in various fish samples from Sir Dam Lake, Kahramanmaras, Turkey. Environ. Monit. Assess. 130 373-379.

Erhabor, CU; Obasohan, EE; Eguavoen, OI (2010). Ecotoxicological studies: Heavy metals contaminating water and fishes from Ibiekuma Stream, Ekpoma, Edo State, Nigeria. Nig. J. Fisheries. 7(1\&2): 81-90.

Farag, AM; May, T; Marty, GD; Easton, M; Harper, DD; et al. (2006). The effect of chronic chromium exposure on the health of Chinook salmon (Oncorhynchus tshawytscha). Aquat. Toxicol. 76: 246-257.

Farombi, EO; Adelowo, OA; Ajimoko, YR (2007). Biomarkers of oxidative stress and heavy metals levels as indicators of environmental pollution in African catfish (Clarias gariepinus) from Ogun River. Int. J. Environ. Res. Public Health, 4(2): 158-165.

Filazi, A; Baskaya, R; Kum, C; Hismiogullar, SE (2003) Metal concentration in tissues of the Black 
sea fish Mugil auratus from Sinop -Icliman, Turkey. Human Exp. Toxicol. 22, 85-87.

Garcia, JC; Martinez, DST; Alves, OL; Leonardo, AFG; Barbieri, E (2015). Ecotoxicological effects of carbofuran and oxidized multiwalled carbon nanotubes on the freshwater fish Nile tilapia: Nanotubes enhance pesticide ecotoxicity. Ecotoxicol. Environ. Saf., 111: 131-137.

Giardina A; Larson BE; Wisner B; Wheeler J; Chao M (2008) Long-term and acute effects of Zinc contamination of a stream on fish mortality and physiology. Environ. Toxic. Chem. 28(2): $287-$ 295.

Golovanova, IL (2008). Effects of heavy metals on the physiological and biochemical status of fishes and aquatic invertebrates. Inland Wat. Bio. 1(1):93101

Javed, M; Usmani, N; Ahmad, I; Ahmad, M (2015). Studies on the oxidative stress and gill histopathology in Channa punctatus of the canal receiving heavy metalloaded effluent of Kasimpur Thermal Power Plant. Environ. Monit. Assess. 187: 4179.

Jezierska, B; Witeska, M (2006). The metal uptake and accumulation in fish living in polluted waters. NATO Science Series, Netherlands: Springer.

Kehinde, AS; Adelakun, KM (2019). Occurrence of heavy metals in selected fish species of River Oli, Kainji Lake National Park, Nigeria. SINET: Ethiop. J. Sci., 42(1):18-24.

Kennedy, CJ; (2011). The toxicology of metals in fishes. Academic Press, San Diego, California, USA.

Kumolu-Johnson, CA; Ndimele, PE; Akintola, SL; Jibuike, CC (2010). Copper, zinc and iron concentrations in water, sediment and Cynothrissa mento (Regan, 1917) from Ologe Lagoon, Nigeria: a preliminary survey. Afr. J. Aquat. Sci., 35(1): 87-94.

Kusemiju, V; Fadiya, AA; Aderinola, OJ; Akintola, SL (2001). Comparative analysis of heavy metals in water, sediments and tissues of Lumbricus violaceus from Agbara and Iba streams. Nig. J. Res. Rev. Sci., 2: 114-117.

Mahboob, S; Al-Ghanim, KA; Al- Balawi, HFA; AlMisned, F; Ahmed, Z (2016). Heavy metals in
Clarias gariepinus (Burchell, 1822) from WadiHanefah, Saudi Arabia. Pak. J. Zoo. 48 (3): 875880 .

Monteiro, SM; Mancera, JM; Fontainhas-Fernandes, A; Sousa, M (2005). Copper induced alterations of biochemical parameter in the gill and plasma of Oreochromis niloticus. Comp. Biochem. Physiol C. 141: 375- 383 .

Murtala, BA; Abdul, WA; Oyebanjo, W; Akinyemi, AA (2012). Bioaccumulation of heavy metals in fish (Hydrocynus forskahlii, Hyperopisus bebe occidentalis and Clarias gariepinus) organs in downstream Ogun coastal water, Nigeria. Trans. J. Sci. Tech. 2 (5): 119-133.

Nhiwatiwa, T; Barson, M; Harrison, AP; Utete, B; and Cooper, RG (2011). Metalconcentrations in water, sediment and sharptooth catfish Clarias gariepinusfrom three peri-urban rivers in the upper Manyame catchment, Zimbabwe. Afr. J. Aquat. Sci. 36: 243-252.

Novozamsky, I; Houba, VJG; van Eck, R; van Vark, W (1983). A novel digestion technique for multielement plant analysis. Com. Soil Sci. Plant Anal. 14: $239-248$

Obianime, AW; Odili, O; Olorunfemi, OJ; Wokoma, TO; Chuemere, AN (2017). Air and soil carcinogenic risk evaluation and impact on the health status of automechanics: The Nigeria Environment. Inter. J. Med. Res. Applica. 1 (1): 26-34.

Obodo, GA (2002). The bioaccumulation of heavy metals in fish from the lower reaches of River Niger. J. Chem. Soc. Nig. 27(2):173-176.

Okafo, CN; Yakubu, SE; Ameh, JB; Okuofu, CA (2018). Heavy metal levels in some fish species harvested from River Kaduna, Nigeria. Afr. J. Nat. Sci. 21: 9-16.

Oliveira-Ribeiro, CA; Vollaire, Y; Sanchez-Chardi, A; Roche, $\mathrm{H}$ (2005). Bioaccumulation and the effects of organochlorine pesticides, PAH and heavymetals in the eel (Anguilla anguilla) at the Camargue Nature Reserve, France. Aquat. Toxicol. 74: 53-69.

Omwenga, JM (2003). Heavy metals and nutrient retention in the Kerenga Wetland, Kericho, Kenya. Unpublished M.Sc. Thesis. 
Pacheco, M; Santos, MA; Pereira, P; Martínez, JI; Alonso, PJ; Soares, MJ; Lopes, JC (2013). EPR detection of paramagnetic chromium in liver of fish (Anguilla anguilla) treated with dichromate (VI) and associated oxidative stress responsesContribution to elucidation of toxicity mechanisms. Comp. Biochem. Physiol. C. 157: 132-140.

Rajappa, B; Manjappa, S; Puttaiah, ET (2010). Monitoring of Heavy metal in groundwater of Hakinaka TaluK, India. Contemp. Eng. Sci. 3(4): $183-190$.

Rashed, MN; (2001). Monitoring of environmental heavy metals in fish from Nasser Lake. Environ. Int. 27: 27-33.

Reid, SD (2011). Molybdenum and chromium. Academic Press, New York, USA.

Sepe, A; Ciaralli, L; Ciprotti, M; Giordano, R; Fumari, E; Costantini, S; (2003). Determination of cadmium, chromium, lead and vanadium in six fish species from the Adriatic Sea. Food Addit. Contam. 20: 543-552.

Sfakianakis, DG; Renieri, E; Kentouri, M; Tsatsakis, AM (2015). Effect of heavy metals on fish larvae deformities: A review. Environ. Res. 137: 246255.

Shukla, V; Dhankhar, M; Prakash, J; Sastry, KV (2007) Bioaccumulation of $\mathrm{Zn}, \mathrm{Cu}$, and $\mathrm{Cd}$ in Channa puntatus. J. Environ. Biol., 28, 395-397.

Sivaperumal, P; Sankar, TV; Viswanathan-Nair, PG (2007). Heavy metal concentrations in fish, shellfish and fish products from internal markets of India vis-a-vis international standards. Food Chem. 102: 612-620.

Steel, RGD; Torrie, J.H (1980). Principle and procedures of statistics. McGraw-Hill New York, USA, pp 633.
Storelli, MM; Barone, G; Storelli, A; Marcotrigiano, GO (2006). Trace metals in tissues of Mugilids (Mugil auratus, Mugil capito andMugil labrosus) from the Mediterranean Sea. Bull. Environ. Contam. Toxicol. 77: 43-50.

Tirkey, A; Shrivastava, P; Saxena, A (2012). Bioaccumulation of heavy metals in different components of two Lakes ecosystem. Current World Environ. 7(2), 293-297.

Uysal, K; Kose, E; Bulbul, M; Donmez, M; Erdogan, Y; Koyun, M; Omeroglu, C; Ozmal, F (2009). The comparison of heavy metal accumulation ratios of some fish species in EnneDarne Lake (Kutahya, Turkey). Environ. Monit. Assess. 157: 355-362.

Vera-Candioti, J; Soloneski, S; Larramendy, ML; (2011). Acute toxicity of chromium on Cnesterodon decemmaculatus (Pisces: Poeciliidae). Theoria 20: 81-88.

Vinodhini, R; Narayanan, M (2008). Bioaccumulations of heavy metals in organs of fresh water fish Cyprinus carpio (Common carp). Int J Environ Sci. Tech. 5: 179-182.

Wangboje, OM; Ekundayo, OT; Iwu, HU (2013). Heavy metal concentrations in two economically important fish species and water of Ovia River, Southern Nigeria. Afr. J. Environ. Pollut. Health. 10:26-32.

World Health Organization, WHO (2008). Guidelines for Drinking Water Quality. 3rd Edn. Health Criteria and Supporting Information. WHO, Geneva, pp: 668. Retrieved from: http://www.who.int/water_sanitation_health/dwq fulltext.pdf. 